\title{
Sending our lungs to rehab: The future of ex vivo lung perfusion?
}

Pablo Sanchez, MD, PhD, and Jonathan D'Cunha, $\mathrm{MD}, \mathrm{PhD}$

\footnotetext{
From the Division of Lung Transplantation/Lung Failure, Department of Cardiothoracic Surgery, University of Pittsburgh Medical Center, Pittsburgh, Pa.

Disclosures: Authors have nothing to disclose with regard to commercial support

Received for publication April 5, 2018; accepted for publication April 9, 2018; available ahead of print May 25, 2018 .

Address for reprints: Jonathan D'Cunha, MD, PhD, Department of Cardiothoracic Surgery, University of Pittsburgh Medical Center, UPMC Presbyterian, Suite C-900, 200 Lothrop St, Pittsburgh, PA 15213 (E-mail: dcunhaj@upmc.edu).

J Thorac Cardiovasc Surg 2018;156:908-9

$0022-5223 / \$ 36.00$

Copyright (c) 2018 by The American Association for Thoracic Surgery

https://doi.org/10.1016/j.jtcvs.2018.04.028
}

The development of ex vivo lung perfusion (EVLP) is centered on the evaluation of lungs of uncertain quality. In 2001, Steen and colleagues ${ }^{1}$ reported the first case of ex vivo perfusion use. Lungs from a patient who died following myocardial infarction after failed cardiopulmonary resuscitation were evaluated ex vivo and transplanted into a patient with chronic obstructive pulmonary disease. Current experiences with donation after circulatory death, particularly under controlled conditions, have questioned the need for ex vivo lung perfusion reassessment. ${ }^{2}$ The International Society of Heart and Lung Transplantation Donation after Circulatory Death registry reported that only $16 \%$ of the transplanted lungs were re-evaluated with ex vivo perfusion. ${ }^{3}$ In our experience, EVLP can aid lung transplant centers in starting their donation after circulatory determination of death (DCDD) programs. In addition, they can support experienced DCDD programs modify their current practices safely, ie, increase times to arrest.

The development of the Toronto method resulted in longer perfusion times. This led centers to consider EVLP as a platform for therapeutics. ${ }^{4}$ Extended EVLP provides a unique opportunity. Donated lungs can be targeted with therapies without concerns for systemic effects or logistic limitations. In addition, the physiological impact of these therapies can be evaluated in real time. Although these interventions have not been approved for clinical use, the era is coming.

The current report by Mehaffey and colleages ${ }^{5}$ is an example of therapies delivered during EVLP with the goal to improve lung quality. The authors investigated the effects of increasing circulating levels of sphingosine-1-phosphate Their rationale was that S1P attenuates lung injury by preserving and promoting vascular integrity via cell-cell junction stabilization. They relied on a mice model of DCDD1 hour of warm ischemia after euthanasia and 1 hour of cold (S1P) during EVLP with the goal of attenuating lung injury.

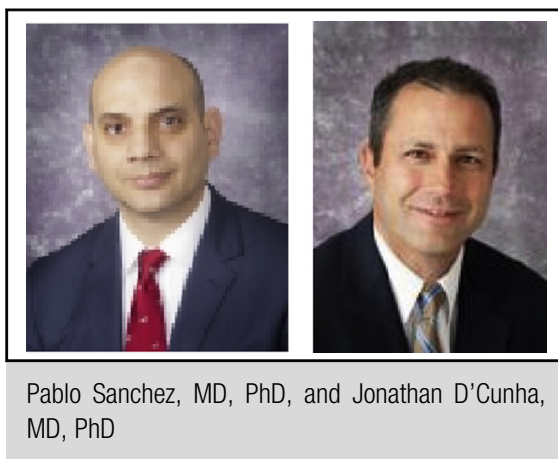

\section{Central Message}

Ex vivo lung perfusion has opened the window to a future of potentially improving lung quality through intervention.

See Article page 910 storage and ex vivo perfusion 1 hour. They increased S1P levels during lung perfusion by adding activated S1P and a SphK2 inhibitor, which in turn reduced S1P clearance.

The mice lungs that underwent EVLP with the addition of S1P+SphKi showed the greatest benefit. The pulmonary artery pressure and lung compliance during EVLP and endothelial integrity were all significantly better when compared with controls. Nevertheless, these results should be interpreted with caution. In this study, the lungs were not reperfused with blood either by adding it at the end of EVLP or by transplanting these organs. In addition, the short period of EVLP may not accurately reflect the quality of the organ or the full benefit of the therapy.

Several encouraging small animal and nonsurvival models testing therapies during EVLP have been published in the last 5 years. Large animal studies that include transplantation and potentially survival surgery should be the standard before these initial reports are translated to clinical trials. We wait with anticipated enthusiasm for these types of investigations to advance our field.

\section{References}

1. Steen S, Sjöberg T, Pierre L, Liao Q, Eriksson L, Algotsson L. Transplantation of lungs from a non-heart-beating donor. Lancet. 2001;357:825-9.

2. Levvey BJ, Harkess M, Hopkins P, Chambers D, Merry C, Glanville AR, et al. Excellent clinical outcomes from a national donation-after-determination-ofcardiac-death lung transplant collaborative. Am J Transplant. 2012;12:2406-13.

3. Cypel M, Levvey B, Van Raemdonck D, Erasmus M, Dark J, Love R, et al. International Society for Heart and Lung Transplantation Donation After Circulatory Death Registry Report. J Heart Lung Transplant. 2015;34:1278-82. 
4. Cypel M, Yeung JC, Hirayama S, Rubacha M, Fischer S, Anraku M, et al. Technique for prolonged normothermic ex vivo lung perfusion. J Heart Lung Transplant. 2008;27:1319-25.
5. Mehaffey JH, Charles EJ, Narahari AK, Schubert S, Laubach VE, Teman NR, et al. Increasing circulating sphingosine-1-phosphate attenuates lung injury during ex vivo lung perfusion. J Thorac Cardiovasc Surg. 2018;156:910-7. 